\title{
Meningkatkan Ketahanan Pangan Dalam Masyarakat \\ (Studi : Sinergi Kelembagaan dalam Implementasi kebijakan Pengadaan Beras di Kab. Banyumas )
}

\author{
Oleh : \\ Hikmah Nuraini \\ Jurusan Ilmu Administrasi Negara FISIP UNSOED \\ Email : Noer_in96@yahoo.com
}

\begin{abstract}
ABSTRAK
Pangan merupakan kebutuhan dasar yang permintaannya terus meningkat seiring dengan perkembangan jumlah penduduk dan peningkatan kualitas hidup, namun demikian dalam beberapa hal definisi atau konsep ketahanan pangan sangat bervariasi pada banyak pihak yang berkepentingan.

Ketahanan pangan mencangkup paling tidak tiga dimensi utama, ketiga dimensi tersebut adalah penyediaan, distribusi dan konsumsi. Kepentingan ketahanan pangan juga menyangkut kepentingan dua sisi, yaitu kepentingan pemerintah dan kepentingan masyarakat. Pemerintah berkepentingan untuk menjamin ketersediaan dan distribusi pangan bagi masyarakat sedangkan masyarakat berkepentingan untuk dapat mengakses pangan.

Untuk dapat mewujudkan ketahanan pangan diperlukan adanya kesatuapaduan lembaga/organisasi yang berkaitan dengan pengadaan panngam yang berinteraksi secara harmonis dalam usaha memenuhi kebutuhan pangan.
\end{abstract}

Kata Kunci : Ketahanan pangan; sinergi kelembagaan

\section{A. PENDAHULUAN}

Pemerintah memandang

ketahanan pangan sebagai hal yang sangat penting dalam rangka pembangunan nasional untuk membentuk manusia Indonesia berkualitas, mandiri, dan sejahtera. Untuk mencapai ketahanan pangan tersebut perlu diwujudkan ketersediaan pangan yang cukup, aman, bermutu, bergizi dan beragam serta tersebar merata di seluruh wilayah Indonesia dan terjangkau oleh daya beli masyarakat. Gabah petani menghasilkan beras yang dikonsumsi sebagai pangan pokok. Dalam sistem ketahanan pangan nasional, beras memiliki peran penting meskipun bukan lagi merupakan bahan pangan satusatunya sumber karbohidrat. Beras merupakan bahan pangan pokok bagi sebagian besar masyarakat Indonesia sejak turun temurun.

Kebutuhan pangan bagi masyarakat nampaknya mengalami peningkatandari tahun ke tahun, keadaan ini dapat dilihat pada tabel berikut ini

\section{Tabel 1. Kebutuhan Beras \\ Penduduk Indonesia Tahun 1971-2011}

\begin{tabular}{|l|l|c|}
\hline Tahun & $\begin{array}{c}\text { Penduduk } \\
\text { (Juta } \\
\text { Jiwa) }\end{array}$ & $\begin{array}{c}\text { Kebutuhan } \\
\text { Beras (000 } \\
\text { ton) }\end{array}$ \\
\hline 1971 & 120 & 17,280 \\
1981 & 151 & 21,744 \\
1991 & 186 & 26,784 \\
2001 & 218 & 31,392 \\
2011 & 245 & 35,280 \\
\hline
\end{tabular}


Sumber: Sumodiningrat (dalam

Tambunan, 2003:179)

Berdasarkan tabel 1 di atas dapat dilihat kebutuhan beras semakin meningkat sejalan dengan pertumbuhan penduduk yang relatif cepat. Oleh karena itu, diperlukan upaya peningkatan ketersediaan beras terutama produksi dari dalam negeri. Upaya untuk menutupi kekurangan beras salah satu langkah yang ditempuh dengan melakukan impor beras. Volume produksi dan impor beras dapat dilihat dalam tabel berikut ini:

Tabel 2. Luas Panen, Produktivitas dan Impor Beras Tahun 2002-2006
Belum terpenuhi kebutuhan beras secara nasional yang masih menyisakan kelemahan ditambah dengan tingkat aksesibilitas masyarakat terhadap pangan khususnya beras masih rendah. Realita ini disebabkan masih banyak masyarakat miskin yang tidak mampu membeli beras dalam memenuhi kebutuhan sehari-hari. Sebagian masyarakat yang tidak mampu membeli beras dalam mencukupi kebutuhan pangan, pemerintah menyediakan Program Raskin (Beras Miskin). Program ini untuk membantu masyarakat dari keluarga miskin agar mampu membeli beras dengan harga yang terjangkau.

\begin{tabular}{|c|c|c|c|c|c|}
\hline Tahun & $\begin{array}{c}\text { Luas } \\
\text { Panen } \\
\text { (000 ha) }\end{array}$ & $\begin{array}{c}\text { Produkti } \\
\text { vitas } \\
\text { (ton/ha) }\end{array}$ & $\begin{array}{c}\text { Produksi } \\
\text { Gabah } \\
\text { (000 ton) }\end{array}$ & $\begin{array}{c}\text { Produksi } \\
\text { Beras } \\
\text { (000 ton) }\end{array}$ & $\begin{array}{c}\text { Impor Beras } \\
\text { (000 ton) }\end{array}$ \\
\hline 2002 & 11,793 & 4,40 & 51,898 & 32,345 & 1,513 \\
2003 & 11,415 & 4,39 & 50,181 & 31,283 & 1,400 \\
2004 & 11,521 & 4,47 & 51,490 & 32,369 & 3,100 \\
2005 & 11,488 & 4,54 & 52,138 & 32,846 & 2,400 \\
2006 & 11,924 & 4,53 & 54,314 & 33,969 & 2,000 \\
\hline
\end{tabular}

Sumber: Badan Pusat Statistik (Berbagai Tahun, dalam Arifin, 2005:85)

Kebijakan impor beras merupakan langkah praktis yang dilakukan pemerintah untuk memenuhi kebutuhan beras nasional. Belum terpenuhinya kebutuhan beras disebabkan: 1) adanya konversi lahan pertanian ke lahan non pertanian; 2) menurunnya kesuburan tanah akibat degradasi kualitas lingkungan; dan 3) ketersediaan air untuk produksi pangan semakin terbatas dan tidak pasti akibat kerusakan hutan; 4) perubahan iklim; serta 5) persaingan pemanfaatan air dengan sektor industri dan pemukiman.

Mengingat peranan beras sangat penting dalam menunjang kehidupan masyarakat, maka pemerintah Indonesia selalu berusaha mencukupi kebutuhan beras tertuang dalam kebijakan pengadaan beras. Landasan hukum kebijakan pengadaan beras adalah UndangUndang Nomor 7 Tahun 1996 tentang Pangan yang merupakan landasan politis-strategis yang mencakup keseluruhan kebijakan yang berhubungan dengan pangan.

Keluarnya Peraturan Pemerintah Nomor 68 tahun 2002 tentang Ketahanan Pangan sebagai peraturan pelaksana Undang-Undang Nomor 7 Tahun 1996 di dalam wilayah organisasi. Peraturan ini 
berfungsi sebagai penghubung antara landasan strategis-politis dengan landasan yang bersifat organisasional dan bahkan berhubungan antarlembaga pemerintah dan lembaga kemasyarakatan. Dalam wilayah implementasi kebijakan pengadaan beras, pemerintah menugaskan kepada Badan Usaha Logistik (Bulog) untuk mengadakan kebutuhan beras dengan Instruksi Presiden Nomor 13 Tahun 2005 tentang Kebijakan Perberasan. Instruksi Presiden Nomor 13 Tahun 2005 menjadi acuan operasional Bulog dalam pengadaan beras.

Bulog merupakan lembaga pangan menjadi komponen sentral dalam melaksanakan kebijakan di bidang perberasan selama kurang lebih 20 tahun. Bulog adalah lembaga pemerintah yang dibentuk pada tahun 1987 yang ditugaskan pemerintah pemerintah untuk melaksanakan salah satu tugas publik yaitu pengelolaan stok beras nasional, walaupun lembaga Bulog telah beralih dari Lembaga Pemerintah Non Departemen (LPND) menjadi Perusahaan Umum (Perum). Perubahan Bulog ini berdasarkan Peraturan Pemerintah No. 7 Tahun 2003 tentang Pendirian Perum Bulog. Pemerintah menyusun tugastugas operasional yang harus dilakukan oleh Perum Bulog menyangkut manajemen stok secara terpusat. Penyebaran stok di berbagai tempat atau gudang sampai ditingkatan daerah dikuasai Bulog. Penguasaan yang dijalankan Perum Bulog untuk memungkinkan secara cepat mengatasi berbagai kerawanan pangan akibat dari bencana alam, konflik, kenaikan harga beras yang tinggi secara mendadak akibat spekulasi dan sebagainya.

\begin{abstract}
Penelitian ini akan mengkaji pada implementasi kebijakan pengadaan beras dan lebih menfokuskan pada sinergi kelembagaan. Kebijakan pengadaan beras merupakan salah satu kebijakan pemerintah sebagai upaya pemenuhan kebutuhan beras untuk menuju ketahanan pangan. Dalam implementasinya, kebijakan pengadaan beras banyak lembaga yang terkait sehingga menarik untuk mengkaji interaksi antar lembaga tersebut.
\end{abstract}

Memahami proses implementasi kebijakan pengadaan beras lebih mudahnya dengan mengunakan pendekatan, yaitu model implementasi menurut Van Meter dan Van Horn. Dimana model ini mengambarkan "proses implementasi kebijakan" dengan memperhatikan keterlibatan berbagai aktor dalam sebuah organisasi dan lintas batas organisasi (Rosyadi, 2006).

Kelembagaan merupakan salah satu aspek penting dalam konteks kebijakan publik karena aspek kelembagaan akan mulai menentukan dalam setiap siklus kebijakan yang dimulai dari perencanaan sampai dengan umpan balik. Bagaimana sebuah kebijakan dirancang, direncanakan, didesain dan diimplementasikan dan dievaluasi akan jelas-jelas membutuhkan partisipasi kelembagaan. Oleh karenanya setiap proses kebijakan yang tidak melibatkan kelembagaan atau tidak menggunakan pendekatan kelembagaan dalam prosesnya akan banyak mengalami kesulitan atau mungkin kegagalan (dalam Badjuri, 2002:37).

Selaian

kelembagaan komunikasi dalam dan antarorganisasi adalah sebuah proses 
yang kompleks dan rumit. Dalam meneruskan pesan-pesan ke bawah dalam suatu organisasi atau dari suatu organisasi ke organisasi lainnya, para komunikator dapat menyimpannya atau menyebarluaskannya, baik secara sengaja atau tidak disengaja. Lebih dari itu, jika sumber-sumber informasi yang berbeda memberikan interpretasi-interpretasi yang tidak konsisten terhadap ukuran-ukuran dasar dan tujuan-tujuan atau jika sumber-sumber yang sama memberikan interpretasi yang bertentangan, para pelaksana akan menghadapai kesulitan yang lebih besar untuk melaksanakan maksudmaksud kebijakan. Oleh karena itu, menurut Van Meter dan Van Horn prospek tentang implementasi yang keberhasilan ditentukan oleh kejelasan ukuran-ukuran dan tujuan yang dinyatakan dan oleh ketepatan dan konsistensi dalam mengkomunikasikan ukuran dan tujuan tersebut (Winarno: 113: 2002).

Pencapaian tujuan kebijakan dipengaruhi juga oleh lingkungan eksternal. Dengan mengidentifikasi pengaruh yang mendalam dari kondisi sosial, ekonomi dan politik terhadap pencapaian badan-badan pelaksana kebijakan. Tjokroamidjojo (1985:54-61)

\section{B. PERUMUSAN MASALAH}

Berdasarkan latar belakang diatas, maka dapatlah dirumuskan permasalahan dalam penelitian ini sebagai berikut : Sejauh mana Sinergi Kelembagaan yang terjadi dalam Implementasi Kebijakan Pengadaan Beras di Kabupaten Banyumas ?

\section{METODE PENELITIAN}

Penelitian ini dilakukan di Kabupaten Banyumas Provinsi Jawa Tengah, dengan sasaran lembagalembaga yang terlibat dalam implementasi kebijakan pengadaan beras di Kabupaten Banyumas. Penelitian ini menggunakan metode Diskriptif kualitatif, dengan pendekatan studi kasus terpancang (embeded case studi). Tehnik pemilihan informan yang digunakan adalah purposive sampling dengan Creterion Based selection yaitu peneliti memilih informan yang dianggap tahu dan dapat dipercaya untuk menjadi data yang mantap dan mengetahui permasalahan secara mendalam dan lebih bersifat selektif, (Sutopo, 1988).

Dalam penelitian ini untuk memperkuat keabsahan data maka digunakan teknik triangulasi sumber dengan membandingkan data hasil pengamatan dan wawancara dengan isi suatu dokumen yang berkaitan. Analisis data yang digunakan dalam penelitian ini adalah kualitatif deskriptif, dengan model yang digunakan analisis interaktif menurut Miles dan Huberman (1992:19).

\section{HASIL PENELITIAN DAN PEMBAHASAN}

Ketahanan pangan adalah terpenuhinya pangan bagi setiap rumah tangga yang tercermin dari tersedianya pangan yang cukup baik jumlah maupun mutunya, aman merata dan terjangkau, pemerintah bersama masyarakat bertanggung jawab untuk mewujudkan ketahanan pangan. Dalam rangka mewujudkan ketahanan pangan, Pemerintah menyelenggarakan pengaturan, 
pembinaan, pengendalian, dan pengawasan terhadap ketersediaan pangan yang cukup, baik jumlah maupun mutunya, aman, bergizi, beragam, merata, dan terjangkau oleh daya beli masyarakat (UndangUndang Nomor 7 Tahun 1996 tentang Pangan)

Menurut Soetrisno (2005:6) strategi yang dapat dibangun dalam membangkitkan ketahanan pangan mencangkup paling tidak tiga dimensi utama. Ketiga dimensi tersebut adalah penyediaan, distribusi dan konsumsi. Menurut Maleha dan Adi (2006:196) Ketahanan pangan (baca : ketahanan beras) merupakan suatu sistem yang terintegrasi yang terdiri atas berbagai subsistem. Subsistem utamanya adalah ketersediaan beras, distribusi beras dan konsumsi beras. Terwujudnya ketahanan pangan merupakan sinergi dari interaksi ketiga subsistem tersebut

Sejak awal pendiriannya, Bulog merupakan salah satu instrumen pelaksana kebijakan pangan nasional. Peran Bulog memang mengalami pasang surut yang dinamis, tetapi alasan keberadaannya tidak pernah terlepas dan tidak dapat dilepaskan dari kerangka kebijakan pangan secara keseluruhan.Badan Urusan Logistik (Bulog) didirikan pada tahun 1967 dengan tugas untuk melakukan pengadaan pembelian beras bagi pemerintah. Bulog merupakan lembaga pangan menjadi komponen sentral dalam melaksanakan kebijakan di bidang perberasan selama kurang lebih 20 tahun. Bulog adalah lembaga pemerintah yang dibentuk pada tahun 1987 yang ditugaskan pemerintah pemerintah untuk melaksanakan salah satu tugas publik yaitu pengelolaan stok beras nasional, walaupun lembaga Bulog telah beralih dari Lembaga Pemerintah Non Departemen (LPND) menjadi Perusahaan Umum (Perum). Perubahan Bulog ini berdasarkan Peraturan Pemerintah No. 7 Tahun 2003 tentang Pendirian Perum Bulog.

Sejalan dengan perubahan Bulog menjadi Perum, maka Perum Bulog mempunyai dua tugas, yaitu tugas publik dan tugas komersial. Dalam tugas publik, Perum Bulog melaksanakan penugasan pemerintah yaitu menyalurkan beras untuk keluarga miskin dan pengamanan stok dalam rangka ketahanan pangan. Tugas komersial Perum Bulog berorientasi untuk mendapatkan profit dengan tetap memperhatikan tugas publik dalam melaksanakan tugas publiknya, antara lain menjamin penyediaan pangan yang merata di seluruh wilayah Indonesia.

Peran penting Perum Bulog terhadap masyarakat adalah menyalurkan beras keluarga miskin (raskin) dan pengamanan stok dalam rangka ketahanan pangan. Untuk memenuhi peran tersebut, Perum Bulog berusaha untuk menjaga kualitas beras yang dimiliki dengan biaya yang telah dikeluarkan, sehingga masyarakat akan puas dan lebih percaya terhadap Perum Bulog namun demikian tetap harus menekan biaya kualitas dengan kuantitas susut bobot.

Pelaksanaan monopoli Badan Urusan Logistik (Bulog) untuk pengadaan beras dan tepung terigu dimaksudkan untuk menghadirkan stabilitas harga kedua komoditi tersebut di masyarakat. Pada awalnya, berdasarkan Keppres Nomor 114/U/KEP/5/1967, Bulog hanya ditugasi untuk pengadaan 
beras. Kemudian, tugas Bulog diperluas sehingga mencakup pengadaan tepung terigu melalui Keppres Nomor 11 Tahun 1969. Sejak diterbitkan keputusan presiden itu, Bulog telah menjadi pemain yang aktif dalam pengadaan kebutuhan sembilan bahan pokok, termasuk beras dan tepung terigu. Dengan perkembangan tersebut, peran Bulog telah bergeser dari sebuah lembaga non departemen yang hanya mengupayakan stabilitas harga dan mengawasi pengadaan beras telah menjadi semi Badan Usaha Malik Negara (BUMN) yang juga mencari untung dalam pengadaan komoditi pangan. Adanya distorsi dalam pelaksanaan monopoli pengadaan beras dan tepung terigu, yang ditunjukkan pada pemberian hak eksklusif untuk turut dalam pengadaan impor beras dan impor gandum sebagai bahan tepung terigu, hal itu jelas bertentangan dengan ketentuan-ketentuan dalam UndangUndang Perbendaharaan Negara (ICW, 2010).

Kesepakatan Pemerintah

Indonesia dan Dana Moneter Internasional (IMF) pada tanggal 15 Januari 1998 telah menyetujui untuk menghapuskan monopoli Bulog untuk pengadaan tepung terigu. Kemudian, menurut Keppres Nomor 19 Tahun 1998, Bulog hanya ditugasi untuk mengendalikan harga dan mengelola persedian beras. Pemenuhan kebutuhan pangan dalam masyarakat dilakukan dengan menjaga keseimbangan kebutuhan pangan yang menitikberatkan pada tiga dimensi, yaitu ketersediaan pangan, aksesibilitas terhadap pangan, dan stabilitas harga pangan. Ketiga dimensi tersebut merupakan fondasi sebagai prasyarat mencapai ketahanan pangan dalam mewujudkan kesejahteraan masyarakat.

Sejak tahun 2000, tugas pokok Bulog adalah melaksanakan tugas pemerintah di bidang manajemen logistik melalui kegiatan pengadaan, pengelolaan persediaan, distribusi dan pengendalian harga beras, serta usaha jasa logistik. Dari seluruh kegiatan tersebut, pengadaan gabah/beras merupakan kegiatan awal yang harus dibenahi terutama pada pemasok gabah/beras yang terdiri dari mitra kerja, PIB (Perberasan Intra Banyumas), dan Drying Center serta Satgas dituntut untuk memasok gabah/beras sesuai dengan standar kualitas yang diterapkan oleh Perum Bulog namun dengan memberikan pelayanan kualitas beras yang sesuai dengan permintaan dan pangsa pasar. Hal ini mewajibkan Perum Bulog untuk lebih mengetahui strategi pengadaan gabah/beras agar dapat mengupayakan pelayanan dalam menghasilkan beras yang berkualitas baik.

Tabel 3. Realisasi Pengadaan Beras
pada Bulog Subdivre IV Banyumas

\begin{tabular}{rccr|} 
Tahun & $\begin{array}{c}\text { Target } \\
\text { (ton) }\end{array}$ & $\begin{array}{c}\text { Realisasi } \\
\text { (ton) }\end{array}$ & $\begin{array}{c}\text { Ketercapaian } \\
(\%)\end{array}$ \\
\hline $\mathbf{2 0 0 6}$ & 93,000 & 102,000 & $109.68 \%$ \\
$\mathbf{2 0 0 7}$ & 92,500 & 97,500 & $105.41 \%$ \\
$\mathbf{2 0 0 8}$ & 112,100 & 107,800 & $96.16 \%$ \\
$\mathbf{2 0 0 9}$ & 119,800 & 109,700 & $91.57 \%$ \\
$\mathbf{2 0 1 0}$ & 121,600 & 115,000 & $94.57 \%$ \\
Rata-rata & & & $99.48 \%$ \\
\hline
\end{tabular}

Sumber : (Laporan Pemeriksaan

Kualitas Gabah, Beras dan Karung

Plastik Di Lingkungan BULOG

Subdivre Banyumas, 2011) 
Selama tiga tahun terakhir pada periode 2006-2010 ternyata pengadaan beras tidak memenuhi target, sementara tahun 2005-2006 melampoi target. Tidak tercapainya target tersebut mengingat di beberapa daerah di Banyumas mengalami gagal panen, atau panen dengan kualitas beras dibawah standar Bulog.

\section{Tabel 4. Pendistribusian Beras} Bulog Subdivre IV Banyumas
Banjarnegara. Pengadaan beras membutuhkan dukungan dari pemerintah daerah sebagai upaya untuk mencukupi kebutuhan pangan bagi masyarakatnya. Upaya yang harus dijalankan pemerintah dengan memfasilitasi penciptaan kondisi yang kondusif dalam pencapaian ketahanan pangan masyarakatnya, melalui instansi terkait dan penyediaan dana pengadaan beras.

\begin{tabular}{ccccc}
\hline Tahun & $\begin{array}{c}\text { Stok } \\
\text { (ton) }\end{array}$ & $\begin{array}{c}\text { Pendistribusian } \\
\text { (ton) }\end{array}$ & $\begin{array}{c}\text { Cadangan } \\
\text { (ton) }\end{array}$ & $\begin{array}{c}\text { Disalurkan } \\
(\%)\end{array}$ \\
\hline $\mathbf{2 0 0 6}$ & 102,000 & 93,922 & 8,078 & $92.08 \%$ \\
$\mathbf{2 0 0 7}$ & 97,500 & 88,871 & 8,629 & $91.15 \%$ \\
$\mathbf{2 0 0 8}$ & 107,800 & 101,677 & 6,123 & $94.32 \%$ \\
$\mathbf{2 0 0 9}$ & 109,700 & 97,732 & 11,968 & $89.09 \%$ \\
$\mathbf{2 0 1 0}$ & 115,000 & 107,088 & 7,912 & $93.12 \%$ \\
Rata-rata & 106,400 & 97,858 & 8,542 & $91.95 \%$ \\
\hline
\end{tabular}

Sumber : (Laporan Pemeriksaan Kualitas Gabah, Beras dan Karung Plastik Di Lingkungan BULOG Subdivre Banyumas, 2011)

Persentase naik turunya jumlah beras yang disalurkan tergantung pada permintaan pasar. Pada saat stok beras di pasar mengalami penurunan dengan indikasi naiknya harga beras, maka Bulog akan segera melakukan operasi pasar. Oleh karena itu jumlah beras yang disalurkan selalu berubah. Sasaran penyaluran beras adalah terutama Raskin, Koperasi, Mitra Bulog dan langsung ke konsumen.

Kebutuhan beras untuk Kabupaten Banyumas harus dipenuhi oleh Perum Bulog di Sub Divisi Regional Wilayah IV Banyumas. Perum Bulog Sub Divisi Regional Wilayah IV Banyumas beroperasi untuk empat kabupaten yakni, Banyumas, Cilacap, Purbalingga, dan
Dukungan dari pemerintah daerah, petani, mitra kerja, KUD sangat penting dalam pemenuhan kebutuhan beras oleh Perum Bulog Sub Divisi Regional Wilayah IV Banyumas. Hubungan yang terjalin antar lembaga akan membentuk sebuah sinergi dalam pengadaan beras sebagai upaya kemandirian pangan. Namun demikian, Dukungan yang diberikan masih menyisakan kelemahan di dalam tataran kelembagaan. Tataran kelembagaan belum terintegrasi satu sama lain masih berdiri sendiri-sendiri dalam menjalankan tugas dan tanggungjawabnya belum ada keseriusan upaya mencapai ketahanan pangan secara kelembagaan. Keadaan ini dapat dilihat masih rendahnya kepedulian pemerintah terhadap nasib petani dan terpenuhinya kebutuhan beras bersifat alamiah terkait dengan kondisi pertanian yang subur, luas 
areal pertanian, dan panen yang melimpah.

Sejalan dengan perubahan Bulog menjadi Perum, maka Perum Bulog mempunyai dua tugas, yaitu tugas publik dan tugas komersial. Dalam tugas publik, Perum Bulog melaksanakan penugasan pemerintah yaitu menyalurkan beras untuk keluarga miskin dan pengamanan stok dalam rangka ketahanan pangan. Tugas komersial Perum Bulog berorientasi untuk mendapatkan profit dengan tetap memperhatikan tugas publik dalam melaksanakan tugas publiknya, antara lain menjamin penyediaan pangan yang merata di seluruh wilayah Indonesia. Distribusi beras pada dasarnya berkaitan erat dengan upaya-upaya yang harus dibangun untuk melancarkan arus ekonomi bahan beras dari point of production (petani produsen) hingga kepada point of consumtion (konsumen akhir) dengan suatu pola distribusi yang efektif dan efisien. Distribusi bertujuan untuk menjamin aksesibilitas beras dan menjamin stabilitas harga beras.

\section{E. PENUTUP}

Pengembangan strategi ketahanan pangan bukan merupakan pekerjaan mudah, dan bukan pula pekerjaan yang sekali dilakukan akan selesai seterusnya. Sistem ketahanan pangan adalah sistem yang dinamis yang memiliki faktor-faktor internal dan eksternal yang dapat berubah setiap waktu. Tantangan pengembangan ketahanan pangan menjadi lebih berat mengingat berbagai kendala dan keterbatasan yang dihadapi pemerintah dan masyarakat,

Jika Perum Bulog masih akan tetap diposisikan sebagai instrumen negara dan peran Bulog memang masih akan dikaitkan dengan usaha mengembangkan ketahanan pangan, maka yang terlebih dahulu perlu ditegaskan adalah strategi ketahanan pangan yang akan dikembangkan. Baru kemudian diturunkan apa sebenarnya peran Bulog dalam strategi meningkatkan ketahanan pangan.

\section{F. DAFTAR PUSTAKA}

Agung, Totok D.H. 2008. Ketahanan Pangan dan Kearifan Lokal, Jurnal Kontribusi, Unsoed Purwokerto.

Arifin, Bustanul. 1994. Pangan dalam Orde Baru. Koperasi Jasa Informasi (Kopindo): Jakarta

Dwiyanto, Agus dkk. 2003. Teladan Dan Pantangan Penyelenggaraan

Pemerintahan Dan Otonomi Daerah. Pusat Studi Kependudukan Dan Kebijakan UGM: Yogyakarta.

Edwards III, George C. 1980. Implementing Public Policy. CQ Press: United States of America

Hendayana, Rachmat dan Y. A. Dewi, 2008, Anatomi Ketahanan Pangan Pada Rumah Tangga Miskin dan Implikasinya Terhadap Kebijakan Inovasi Pertanian. Balai Besar Pengkajian dan 
Pengembangan Teknologi

Pertanian

http://Ftp.Ui.Edu diakses

tanggal 26 Oktober 2007

Instruksi Presiden RI Nomor 7

Tahun 2009 tentang

Kebijakan Perberasan

Lesmana, Teddy. 2007, Ketahanan Pangan dan Pemberantasan

Kemiskinan.

www.LIPI.go.id. Diakses pada tanggal 07 Juni 2011

Maleha dan Sutanto, Adi. 2006. Kajian Konsep Ketahanan Pangan. Jurnal Portein

Meter, Van and Van Horn. "The Policy Implementation Process: A Conceptual Framework".

Administration

\& Society, Vol. 6, No. 27, Februari, 1975

Miles, M. dan A.M. Huberman. 1992. Analisis Data Kualitatif, penerjemah Tjetjep Rohendi Rohadi, UI Press, Jakarta

Moleong, Lexy. 2000. Metode Penelitian Kualitatif, Remaja Rosdakarya Bandung

Morrison , D.M, Mohaski, K \& Cotter, K. 2005. Instructional quality
Indicators research foundations. Cambridge, MA : Connect

Mubyarto. 1986. Pengantar Ekonomi Pertanian. LP3ES: Jakarta

Muhammad, Arni. 2004. Komunikasi Organisasi. Bumi

Pace, R. Wayne dan Don F. Faules. 1998. Komunikasi Organisasi: $\quad$ Strategi Meningkatkan Kinerja Perusahaan. PT Remaja Rosdakarya: Bandung.

Purwadarminta, W.J.S.1988, Kamus Umum Bahasa Indonesia, Balai Pustaka, Jakarta

Simon, Herbert A. 1958. Administrative Bahavior. Mac Millan Co : New York

Sutopo, Heribertus, 1988. Pengantar Penelitian kualitatif: Dasar-Dasar Teoritis dan Praktis, Pusat Penelitian Universitas Sebelas Maret, Surakarta.

Tjokroamijojo, Bintoro,1984 PengantarAdministrasi Pembangunan, LP3ES, Jakarta.

Wahab, Solihin. Abdul, 2002. Analisis Kebijaksanaan: dari Formulasi ke Implementasi Kebijakan Negara, Bumi Aksara Bandung 
Wibawa, Samudra dkk, 1994.

Evaluasi Kebijakan

Publik, PT Raja

graffindo, Jakarta.

Winarno, Budi. 2002. Teori dan Proses Kebijakan

Publik. Media Pressindo:

Yogyakarta 